\title{
CLINICAL EXPERIENCE WITH ORG NC45 (NORCURON) AS THE SOLE MUSCLE RELAXANT
}

\author{
A. Williams, H. Gyasi, C. Melloni and D.R. Bevan
}

\begin{abstract}
The neuromuscular effects of ORG NC45, used as the solc muscle relaxant, were compared with a succinylcholine-pancuronium sequence in patients during nitrous oxide-fentanyl anaesthesia. The subjects were divided into four groups with ten in each group. After induction of anaesthesia they received either succinylcholine, $1 \mathrm{mg} \cdot \mathrm{kg}^{-1}$ or ORG NC45 in doses of 50,70 or $90 \mu \mathrm{g} \cdot \mathrm{kg}^{-1}$ and tracheal intubation was done 90 seconds later. Neuromuscular transmission was monitored using train-of-four stimulation. Succinylcholine produced 100 per cent block with uniformly excellent intubating conditions whereas the three doses of ORG NC45 werc associated with blocks of 7.5, 18.7 and 30.7 per cent and acceptable conditions in only 30 per cent of subjects.

Muscle relaxation was maintained in the $\mathrm{NC} 45$ groups with increments of $10 \mu \mathrm{g} \cdot \mathrm{kg}^{-1}$ and in the succinylcholine group with pancuronium, initially as a bolus of $40 \mu \mathrm{g} \cdot \mathrm{kg}^{-1}$, followed by increments of $5 \mu \mathrm{g} \cdot \mathrm{kg}^{-1}$. All increments were given at 10 per cent recovery of twitch height. The overall requirement to maintain 90 per cent block with pancuronium was $1.1 \mu \mathrm{g} \cdot \mathrm{kg}^{-1} \cdot \mathrm{min}^{-1}$ compared with $1.28 \mu \mathrm{g} \cdot \mathrm{kg}^{-1} \cdot \mathrm{min}^{-1}$ with ORG NC45. No cumulative effects were seen with either drug during the first hour of neuromuscular blockade.

At the end of the operation the neuromuscular block was antagonized with atropine $18 \mu \mathrm{g} \cdot \mathrm{kg}^{-1}$, and neostigmine $36 \mu \mathrm{g} \cdot \mathrm{kg}^{-1}$ and recovery was significantly more rapid with $\mathrm{NC45}$ than pancuronium.

We conclude that the lack of cumulation, easy reversibility and lack of cardiovascular effects suggest that NC45 has advantages over currently available non-depolarizing muscle relaxants but that its onset of action is too slow for rapid intubation.
\end{abstract}

Key Words: Neuromuscular Relaxants, ORG NC45 (Norcuron).

ORG NC45 (NoRCLRON), a monoquaternary analogue of pancuronium, is a neuromuscular blocking drug which has been released for clinical trial in North America. In man, NC45 has been shown to be faster in onset, of shorter duration and more easily antagonized with neostigmine than pancuronium. ${ }^{1-3}$ In animals, NC45 has little or no cardiovascular actions ${ }^{4}$ and preliminary reports suggest that this stability also occurs in man. ${ }^{5}$

The present study was designed to compare $\mathrm{NC45}$ as the sole neuromuscular blocking drug with a combination of succinylcholine for intubation and pancuronium for maintenance during operations of similar duration and using a similar anaesthetic sequence. In particular, comparisons

A. Williams, M.B., B.S., F.F.A.R.C.S., H. Gyasi, M.B., B.S., F.F.A.R.C.S.I., and C. Melloni, M.D., Clinical Fellows; D.R. Bevan, M.B., M.R.C.P., F.F.A.R.C.S., Associate Professor; Departments of Anaesthesia, Royal Victoria Hospital \& McGill University, 687 Pine Avenue West, Montreal, Quebec, $\mathrm{H} 3 \mathrm{~A} 1 \mathrm{~A} 1$. were made of intubating conditions, of relaxant requirements and cumulative tendency during maintenance and of the rates of antagonism after neostigmine.

\section{Methods}

The protocol was approved by the Hospital Ethics Committee. After informed written consent had been obtained 40 healthy adult patients were studied. All were classed as ASA I or II, were free of neuromuscular, hepatic or renal disease, had no electrolyte imbalance and were not taking drugs known to interfere with neuromuscular transmission. All patients were premedicated with atropine or hyoscine and an opiate, meperidine or morphine, in doses commensurate with their age and weight.

Anaesthesia was induced with thiopentone $3-5 \mathrm{mg} \cdot \mathrm{kg}^{-1}$ and fentanyl $3-4 \mu \mathrm{g} \cdot \mathrm{kg}^{-1}$, and maintained with 70 per cent nitrous oxide with oxygen, supplemented with fentanyl 1-1.5

Can. Anaesth. Soc. J., vol. 29, no. 6, November 1982 
TABLE 1

Neuromuscular Blocking Drug Regimens

\begin{tabular}{cllll}
\hline \hline Group & \multicolumn{2}{c}{ Intubation } & \multicolumn{2}{c}{ Maintenance } \\
\hline 1 & Succinylcholine $1 \mathrm{mg} \cdot \mathrm{kg}^{-1}$ & Pancuronium $40 \mu \mathrm{g} \cdot \mathrm{kg}^{-1}$ \\
& & & followed by $5 \mu \mathrm{g} \cdot \mathrm{kg}^{-1}$ \\
2 & $\mathrm{NC45}$ & $50 \mu \mathrm{g} \cdot \mathrm{kg}^{-1}$ & $\mathrm{NC45}$ & $10 \mu \mathrm{g} \cdot \mathrm{kg}^{-1}$ \\
3 & $\mathrm{NC45}$ & $70 \mu \mathrm{g} \cdot \mathrm{kg}^{-1}$ & $\mathrm{NC45}$ & $10 \mu \mathrm{g} \cdot \mathrm{kg}^{-1}$ \\
4 & $\mathrm{NC45}$ & $90 \mu \mathrm{g} \cdot \mathrm{kg}^{-1}$ & $\mathrm{NC45}$ & $10 \mu \mathrm{g} \cdot \mathrm{kg}^{-1}$ \\
\hline
\end{tabular}

$\mu \mathrm{g} \cdot \mathrm{kg}^{-1}$ every thirty minutes. After tracheal intubation, ventilation was controlled and the minute volume was adjusted to maintain an end-tidal $\mathrm{PCO}_{2}$ of $4.6-5.3 \mathrm{kPa}$ (35-40 torr) (Hewlett Packard infrared carbon dioxide analyzer HP47210A). Pulse, blood pressure and electrocardiogram were monitored and body temperature, using oesophageal and/or skin probes, was maintained above $34^{\circ} \mathrm{C}$.

Neuromuscular function was assessed according to the method of Ali, Utting and Gray. ${ }^{6}$ The ulnar nerve was stimulated supramaximally at the elbow using subcutaneous needle electrodes. Trains-of-four with square pulses of $0.2 \mathrm{~ms}$ duration at a frequency of $2 \mathrm{~Hz}$ and a train duration of $2 s$ were repeated every $10 \mathrm{~s}$ using a Grass S48 stimulator and a SIU5 Isolation Unit. The hand and forearm were immobilized in a splint and the force of contraction of the adductor pollicis was measured with a force-displacement transducer (Grass F.T. 10) and recorded using a pen-and-ink recorder (Grass Polygraph).

The patients were divided randomly into four groups with ten patients in each group for the choice of neuromuscular blocking regimens (Table I). Following stabilization of the train-offour recordings the intubating drug was injected into a fast-running infusion. Intubation was attempted 90 s later and the conditions were scored according to the method of Fahey, et al. ${ }^{3}$ (Table II).

Neuromuscular blockade was maintained in group 1 with pancuronium in an initial bolus of $40 \mu \mathrm{g} \cdot \mathrm{kg}^{-1}$, after full recovery from succinylcholine had been demonstrated by restoration of twitch height to control values. This was followed by repeated boluses of $5 \mu \mathrm{g} \cdot \mathrm{kg}^{-1}$ whenever the height of the first twitch of the train reached 10 per cent of control. In groups $2-4$ repeated boluses of $\mathrm{NC45} 10 \mu \mathrm{g} \cdot \mathrm{kg}^{-1}$ were administered at 10 per cent twitch recovery. When the initial twitch suppression was less than 90 per cent similar doses were given when two consecutive twitches were of the same height. At the end of the operation atropine $17 \mu \mathrm{g}^{\mathrm{kg}} \mathrm{g}^{-1}$, and neostigmine $36 \mu \mathrm{g} \cdot \mathrm{kg}^{-1}$ were given at 10 per cent recovery and muscle twitch activity was followed for 10 minutes or until train-of-four ratio (T4/T1), the height of the first twitch as a percentage of the first in each train, reached 70 per cent.

The mean values are presented with the standard error of the mean as the index of dispersion. Probabilities were calculated from Student's t test for unpaired data where appropriate and the null hypothesis was rejected when $\mathrm{P}<0.05$.

\section{RESULTS}

The four groups of patients were comparable with respect to age, sex, weight and duration of anaesthesia (Table III).

\section{Intubating Conditions - Onset of Neuro-} muscular Blockade

In all patients the trachea was intubated 90 seconds after administration of either succinylcholine or NC45, but the intubating conditions with NC45 were poor even at the highest dose (Table IV). If scores of 0 and $I$ are considered acceptable conditions these were achieved in all patients receiving succinylcholine but only in 30 per cent receiving $\mathrm{NC45}$.

The percentage twitch depression at 90 seconds and at maximum block and the times taken

TABLE II

SCORING OF INTUBATING CONDITIONS

\begin{tabular}{|c|c|}
\hline Score & Conditions \\
\hline 0 & $\begin{array}{l}\text { Cords abducted, good visualization, no } \\
\text { patient movement }\end{array}$ \\
\hline 1 & $\begin{array}{l}\text { Cords abducted, good visualization, dia- } \\
\text { phragmatic movement with intubation }\end{array}$ \\
\hline 2 & $\begin{array}{l}\text { Cords slightly abducted, fair visualization, } \\
\text { coughing with intubation }\end{array}$ \\
\hline 3 & $\begin{array}{l}\text { Cords moderately abducted, poor visuali- } \\
\text { zation, gross body movement with } \\
\text { intubation }\end{array}$ \\
\hline
\end{tabular}


TABLE III

Patient Data in NC45 and Pancuronium (PCB) Groups

\begin{tabular}{|c|c|c|c|c|c|c|c|}
\hline \multirow[b]{2}{*}{ Group } & \multirow{2}{*}{$\begin{array}{c}\text { Agent and } \\
\text { initial dose } \\
\mu \mathrm{g} \cdot \mathrm{kg}^{-1}\end{array}$} & \multirow{2}{*}{$\begin{array}{l}\text { Age } \\
\text { years }\end{array}$} & \multirow{2}{*}{$\begin{array}{l}\text { Sex } \\
M: F\end{array}$} & \multirow{2}{*}{$\begin{array}{c}\text { Weight } \\
\mathrm{kg}\end{array}$} & \multirow{2}{*}{$\begin{array}{l}\text { Duration } \\
\text { minutes }\end{array}$} & \multicolumn{2}{|c|}{ Total dose, $\mathrm{mg} \cdot \mathrm{kg}^{-1}$} \\
\hline & & & & & & NC45 & $\mathrm{PCB}$ \\
\hline 1 & Succ/PCB 40 & $57.0 \pm 6.1$ & $2: 8$ & $66.4 \pm 3.2$ & $84.8 \pm 19.5$ & - & $4.4 \pm 0.5$ \\
\hline 2 & $\begin{array}{ll}\mathrm{NC} 45 & 50\end{array}$ & $62.5 \pm 5.1$ & $7: 3$ & $68.3 \pm 4.0$ & $103.2 \pm 34.1$ & $9.4 \pm 1.3$ & - \\
\hline 3 & NC45 & $50.3 \pm 6.1$ & $5: 5$ & $64.1 \pm 7.7$ & $81.7 \pm 12.0$ & $9.7 \pm 1.1$ & - \\
\hline 4 & NC45 & $52.6 \pm 5.2$ & $6: 4$ & $68.8 \pm 5.6$ & $131.6 \pm 23.1$ & $13.3 \pm 2.0$ & - \\
\hline
\end{tabular}

to achieve maximum, or 100 per cent, block for each of the agents are shown in Table $\mathrm{V}$. The times to recovery of twitch activity to 10 per cent of control values after NC45 are also given. Succinylcholine produced 100 per cent block in all subjects in $1.1 \pm 0.1 \mathrm{~min}$. The blockade after $\mathrm{NC} 45$ occurred more slowly although it was accelerated as the dose was increased (Figure 1). The mean maximum block after $50 \mu \mathrm{g} \cdot \mathrm{kg}^{-1}$ was of $91.4 \pm 3.8$ percent in $6.7 . \pm 0.4$ minutes; after $70 \mu \mathrm{g} \cdot \mathrm{kg}^{-1}$ it was $99.2 \pm 0.2$ per cent in $4.1 \pm$ 0.4 minutes and after $90 \mu \mathrm{g} \cdot \mathrm{kg}^{-1}$ it was 100 per cent in $3.9 \pm 0.3$ minutes. The duration of action of NC45 increased with the larger doses of NC45 and a dose of $90 \mu \mathrm{g} \cdot \mathrm{kg}^{-1}$ the mean time to $10 \mathrm{per}$ cent recovery was 33.4 minutes.

\section{Maintenance of Neuromuscular Blockade}

After the establishment of neuromuscular blockade with $\mathrm{NC45}$ or pancuronium the durations of action of subsequent doses, given when twitch activity recovered to 10 per cent of control, are shown in figure 2. During the first hour of neuromuscular blockade cumulation was not observed with either drug. The maintenance dose requirements for $\mathrm{NC45}$ and pancuronium are shown in figure 3 . There was a tendency for the subsequent requirement for NC45 to decrease, the larger the initial dose, but the differences were not statistically significant. The overall requirements to maintain 90 per cent block were similar for both drugs: the mean value for

TABLE IV

\begin{tabular}{|c|c|c|c|c|}
\hline \multicolumn{5}{|c|}{ ' INTUBATING CONDITIONS } \\
\hline \multirow[b]{2}{*}{ Agent } & \multicolumn{4}{|c|}{ Intubating Score } \\
\hline & 0 & 1 & 2 & 3 \\
\hline $\begin{array}{l}\text { Succinylcholine } \\
\text { NC45: } 50 \mu \mathrm{g} \cdot \mathbf{k g}^{-1} \\
70 \mu \mathrm{g} \cdot \mathrm{kg}^{-1} \\
90 \mu \mathrm{g} \cdot \mathrm{kg}^{-1}\end{array}$ & $\begin{array}{r}10 \\
1 \\
0 \\
0\end{array}$ & $\begin{array}{l}0 \\
1 \\
4 \\
3\end{array}$ & $\begin{array}{l}0 \\
2 \\
3 \\
2\end{array}$ & $\begin{array}{l}0 \\
6 \\
3 \\
5\end{array}$ \\
\hline
\end{tabular}

(Adapted from Fahey, et al., 1981).

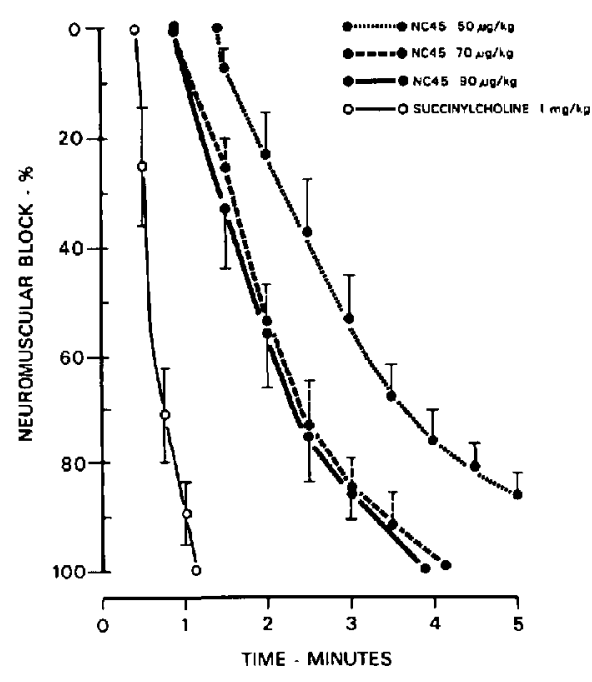

Figure 1 Speed of onset of neuromuscular block with succinylcholine and NC45 (mean \pm sem).

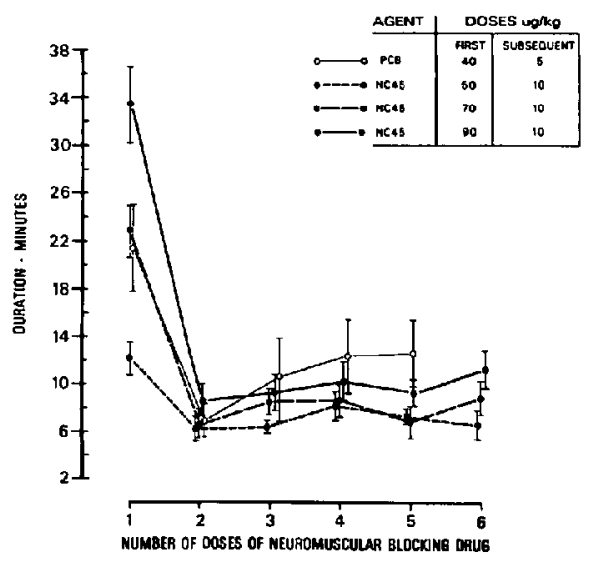

FIgURE 2 Durations of action, from time of administration to 10 per cent recovery, of initial and subsequent doses of pancuronium (PCB) and NC45 (mean \pm sem). 
TABLE $\mathrm{V}$

ONSET, Intensity and DURATION of Neuromuscular Block

\begin{tabular}{|c|c|c|c|c|}
\hline \multirow[b]{2}{*}{ Agent } & \multicolumn{2}{|c|}{ Neuromuscular block \% } & \multirow{2}{*}{$\begin{array}{l}\text { Time to } \\
\max \\
(\min )\end{array}$} & \multirow{2}{*}{$\begin{array}{l}\text { Time to } 10 \% \\
\text { recovery } \\
\text { (min) }\end{array}$} \\
\hline & At $90 \mathrm{~s}$ & $\operatorname{Max}$ & & \\
\hline Succinylcholine & 100 & 100 & $1.1 \pm 0.1$ & \\
\hline $\begin{aligned} & \text { NC45: } 50 \mu \mathrm{g} \cdot \mathrm{kg}^{-1} \\
& 70 \mu \mathrm{g} \cdot \mathrm{kg}^{-1} \\
& 90 \mu \mathrm{g} \cdot \mathrm{kg}^{-1}\end{aligned}$ & $\begin{array}{r}7.5 \pm 2.2 \\
18.7 \pm 5.7 \\
30.7 \pm 10.2\end{array}$ & $\begin{array}{r}91.4 \pm 3.8 \\
99.2 \pm 0.2 \\
100\end{array}$ & $\begin{array}{l}6.7 \pm 0.4 \\
4.1 \pm 0.4 \\
3.9 \pm 0.3\end{array}$ & $\begin{array}{l}14.3 \pm 1.8 \\
22.6 \pm 2.2 \\
33.4 \pm 3.2\end{array}$ \\
\hline
\end{tabular}
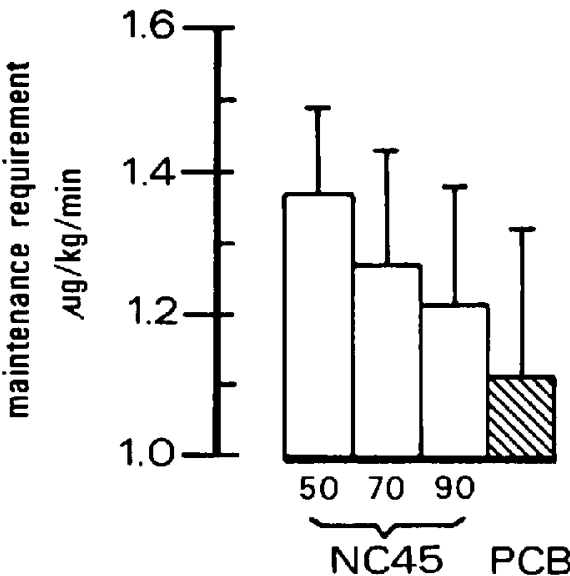

FIgURE 3 Maintenance dose requirements $\mu \mathrm{g}$ $\mathrm{kg}^{-1} \cdot \mathrm{min}^{-1}$ for the three groups receiving NC45 compared with pancuronium (PCB) (mean \pm sem).
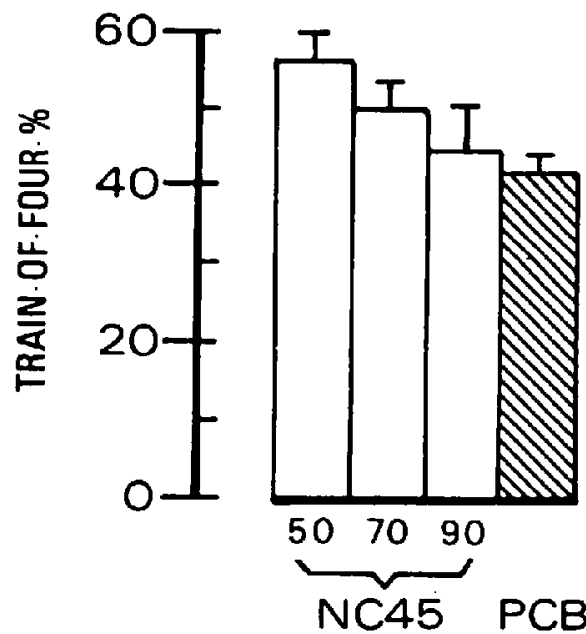

Figure 4 Train-of-four per cent, five minutes after administration of atropine and neostigmine for the three groups receiving NC45 compared with pancuronium (PCB) (mean \pm sem). all NC45 patients was $1.28 \pm 0.1 \mu \mathrm{g} \cdot \mathrm{kg}^{-1} \cdot \mathrm{min}^{-1}$ compared with $1.11 \pm 0.2 \mu \mathrm{g} \cdot \mathrm{kg}^{-1} \cdot \mathrm{min}^{-1}$ for pancuronium.

\section{Recovery after Neostigmine}

The train-of-four recoveries five minutes after antagonism of the block with neostigmine are shown in figure 4 . There was a tendency for recovery to be more rapid after the smaller initial doses of NC45 but this was not statistically significant. When the five minute recoveries of all the patients who received NC45 were accumulated the mean train-of-four was $50.6 \pm 2.6$ per cent compared with $41.6 \pm 2.5$ per cent for pancuronium and this difference was statistically significant $(\mathrm{P}<.05)$.

\section{Discussion}

In general, the results of this study are in agreement with previous reports. NC45 is a non-depolarizing neuromuscular blocking drug which is more potent and shorter acting than pancuronium and is easily antagonized with neostigmine.

Agoston, et al. ${ }^{2}$ using a similar anaesthetic technique, reported that NC45 in a dose of 80 $\mu \mathrm{g} \cdot \mathrm{kg}^{-1}$ provided ideal intubating conditions in $90-95$ seconds. We found acceptable intubating conditions in only 3 of 10 patients who received $90 \mu \mathrm{g} \cdot \mathrm{kg}^{-1}$, although the intensity and timing of the depression of the evoked twitch response were similar in both studies. Our results are in accord with Harrison and Feldman who found good intubating conditions in only 50 per cent of subjects after NC45 $100 \mu \mathrm{g} \cdot \mathrm{kg}^{-1}$. ${ }^{7}$ If NC45 is to be used for tracheal intubation this could be achieved either by waiting until maximal blockade is achieved, or by increasing the dose to at least $140 \mu \mathrm{g} \cdot \mathrm{kg}^{-1}$, or by the concomitant administration of inhalational anaesthetic agents. ${ }^{8}$ However, the rapid onset of intense neuromuscular blockade of short duration, actions which are important for the emergency patient with a 
full stomach, can only be achieved with succinylcholine which we found produced excellent intubating conditions in all subjects within 90 seconds of its administration.

Maintenance of 90 per cent neuromuscular block was achieved easily with both drugs. Because NC45 is more potent and has a shorter duration of action than pancuronium the maintenance requirement for both drugs was similar and was approximately $1 \mu \mathrm{g} \cdot \mathrm{kg}^{-1} \cdot \mathrm{min}^{-1}$. The small doses used in this study necessitated frequent "top-up" administration. If the requirement does not change with larger doses then the approximate requirement for each agent using nitrous oxide narcotic anaesthesia would be $0.1 \mathrm{mg}$ per $\mathrm{min}$ for a $70 \mathrm{~kg}$ adult. In this study the duration of the surgical procedures was relatively short - average duration of neuromuscular block was less than two hours - and during that time cumulative effects were not observed with either drug. Cumulation, even with pancuronium, appears to be important only for much longer procedures ${ }^{3}$ and further studies with exposure to $\mathrm{NC45}$ for a similar duration are necessary before the possibility of its occurrence can be denied.

Recovery of neuromuscular function occurred rapidly in patients receiving either NC45 or pancuronium. Fahey, et al. have demonstrated that when antagonism of neuromuscular blockade was achieved with repeated boluses of neostigmine less was required to antagonize $\mathrm{NC} 45^{3}$ than was necessary to antagonize a similar degree of neuromuscular blockade with pancuronium. ${ }^{9}$ We found that when neostigmine was administered as a single bolus the rate of recovery of neuromuscular function was slightly, but significantly, more rapid with $\mathrm{NC45}$ than with pancuronium.

In summary, NC45 is a non-depolarizing neuromuscular blocking drug which is more potent than pancuronium and has a shorter duration of action. Intubating conditions are unsatisfactory 90 seconds after bolus doses of 50,70 and $90 \mu \mathrm{g} \cdot \mathrm{kg}^{-1}$. However, maintenance of muscle relaxation can be achieved with doses of approximately $1 \mu \mathrm{g} \cdot \mathrm{kg}^{-1} \cdot \mathrm{min}^{-1}$ without cumulative effects, at least for operations lasting up to two hours. In addition, its rate of antagonism by neostigmine is quicker than pancuronium.

\section{REFERENCES}

1. Crul, J.F. \& Boou, L.H.D. First clinical experiences with ORG NC45. Br. J. Anaesth. 52:49S (1980).

2. Agoston, S., Salt, P., Newton, A., Bencin1, P., Boomsma, P. \& ERdManN, W. The neuromuscular blocking action of ORG NC45, a new pancuronium derivative, in anaesthetized patients. Br. J. Anaesth. 52: 53S (1980).

3. FAHEY, M.R., MORRIS, R. B., MILler, R.D., SoHn, Y.J., CronNell y, R. \& GenCarelli, P. Clinical pharmacology of ORG NC45 (Norcuron): a new non-depolarizing muscle relaxant. Anesthesiology, 55: 6 (1981).

4. Bools, L.H.D.J., EDWards R.P., Sohn, Y.J. \& MilleR, R.D. Cardiovascular and neuromuscular effects of ORG NC45, pancuronium, metocurine, and d-tubocurarine in dogs. Anesth. Analg. 59:26 (1980)

5. Krieg, N, Crul, J.F. \& BoolJ, L.H.D.J. Relative potency of ORG NC45, pancuronium, alcuronium and tubocurarine in anaesthetized man. Br. J. Anaesth. 52: 783 (1980).

6. Ali, H.H., UtTing, J.E. \& Gray, C. Stimulus frequency in the detection of neuromuscular block in humans. Br. J. Anaesth. 42:967 (1970).

7. Harrison, P. \& FELDMAN, S.A. Intubating conditions with ORG NC45. Anaesthesia 36: 874 (1981).

8. Fahey, M.R., Morris, R.B., Miller, R.S., SOHN, Y.J. \& CronNelly, R. Can Norcuron be used for intubation? Anesthesiology 53: $\mathrm{S} 273$ (1980).

9. Miller, R.D., Larson, C.P. \& WAY, W.L. Comparative antagonism of d-tubocurarine-, gallamine-, and pancuronium-induced neuromuscular blockades by neostigmine. Anesthesiology 37: 503 (1972).

\section{RÉSUME}

La qualité du relâchement musculaire produit par le norcuron (ORG NC45) utilisé comme seul agent de curarisation a été comparée à celle obtenue avec l'emploi séquentiel de succinylcholine (pour l'intubation) et de pancuronium (pour le reste de l'intervention chirurgicale), ceci au cours d'interventions effectuées sous anesthésie au protoxyde d'azote supplémenté de fentanyl.

Quatre groupes de dix patients chacun ont été constitués aux fins de l'étude. Après l'induction de l'anesthésie (thiopental et fentanyl), on administrait aux patients, selon leur groupe, de la succinylcholine $1 \mathrm{mg} \cdot \mathrm{kg}^{-1}$ ou du norcuron à la dose de 50,70 ou $90 \mu \mathrm{g} \cdot \mathrm{kg}^{-1}$; I'intubation était effectuée 90 secondes plus tard. La qualité du bloc neuromusculaire était évaluée au moyen d'une "série de quatre" (train-of-four). La succinylcholine produisait de 
façon constante un bloc à 100 pour cent se traduisant par des conditions d'intubation idéales. Le NC45 pour sa part produisait selon les doses des bloes respectifs de 7.5, 18.7 et 30.7 pour cent et les conditions d'intubation n'étaient jugées acceptables que dans 30 pour cent des cas.

Le relâchement per-operatoire était obtenu dans le cas des groupes recevant le norcuron, au moyen de doses fractionnées de $10 \mu \mathrm{g} \cdot \mathrm{kg}^{-1}$ de NC45; dans le cas des malades ayant reçu de la succinylcholine pour l'intubation, une première dose de $40 \mu \mathrm{g} \cdot \mathrm{kg}^{-1}$ de pancuronium était administrée pour produire le relâchement musculaire nécessaire à la chirurgie et des doses de rappel de $5 \mu \mathrm{g} \cdot \mathrm{kg}^{-1}$ du même agent étaient répétées au besoin. Le maintien d'un bloc de 90 pour cent requérait des doses de $1.1 \mu \mathrm{g} \cdot \mathrm{kg}^{-1} \cdot \mathrm{min}^{-1}$ de pancuronium alors qu'il nécessitait $1.28 \mu \mathrm{g} \cdot \mathrm{kg}^{-1} \cdot \mathrm{min}^{-1}$ dans le cas du NC45. On n'a pas observé d'effets cumulatifs au cours de la première heure dans les deux cas.

En fin de chirurgie, le bloc était renversé au moyen d'atropine $18 \mu \mathrm{g} \cdot \mathrm{kg}^{-1}$ et de néostigmine $36 \mu \mathrm{g} \cdot \mathrm{kg}^{-1}$; la récupération était significativement plus rapide avec le norcuron qu'avec le pancuronium.

En conclusion, le NC45 présente des avantages sur les autres agents non dépolarisants présentement disponibles (absence d'effets cumulatifs et d'effets cardiovasculaires, reversibilité facile du bloc); sa vitesse d'action est trop lente pour en faire un agent d'intubation rapide. 